\title{
EFEKTIVITAS PEMBELAJARAN DARING WAWASAN KEBANGSAAN
}

\author{
Afnan Fuadi \\ ${ }^{1}$ Balai Diklat Aparatur Kementerian Kelautan dan Perikanan \\ ${ }^{1}$ afnanfuadi@gmail.com \\ https://doi.org/10.36052/andragogi.v9i1.194 \\ Diterima: 25 Januari 2021 | Disetujui: 23 Mei 2021 | Dipublikasikan: 30 Juni 2021

\begin{abstract}
Abstrak
Penelitian ini bertujuan untuk mengetahui efektivitas pembelajaran daring Wawasan Kebangsaan dalam Pelatihan Dasar CPNS Golongan II Tahun 2020 di Balai Diklat Aparatur (BDA) Kementerian Kelautan dan Perikanan. Penelitian ini merupakan penelitian kuasi eksperimen dengan pendekatan kuantitatif. Metode pengumpulan data melalui lembar penugasan, kuesioner dan wawancara. Indikator efektivitas pembelajaran adalah seluruh peserta mendapatkan nilai post test dengan skor minimal 80 dan minimal $80 \%$. Sampel penelitian adalah seluruh peserta Latsar Golongan II Angkatan Tahun 2020 berjumlah 16 orang. Hasil penelitian menunjukkan bahwa nilai ratarata pre test 84.5 dan nilai rata-rata post test 97.5 , yang berarti mengalami peningkatan sebesar $015.4 \%$. Berdasarkan hasil kuesioner, diperoleh hasil bahwa metode pembelajaran daring Wawasan Kebangsaan dinilai efektif oleh peserta dalam mencapai tujuan pembelajaran. Pola pembelajaran Wawasan Kebangsaan daring Latsar CPNS Golongan II Tahun 2020 dengan segala kelebihan dan kekurangannya dinilai efektif dalam mencapai tujuan pembelajaran sehingga dapat terus dilanjutkan baik dalam kondisi new normal maupun kondisi normal.
\end{abstract}

Kata Kunci: efektivitas, pembelajaran daring, wawasan kebangsaan, latsar CPNS

\begin{abstract}
[EFFECTIVENESS OF NATIONAL INSIGHTS ONLINE LEARNING]. This study aims to determine the effectiveness of national insight online learning in Basic Training for Civil Servant Candidate Group II 2020 at Apparatus Training Center of Ministry of Maritime Affairs and Fisheries. This study was a quasi experimental research with a quantitative approach. The data was collected using assignment sheet, questionnaire and interview. The learning effectiveness indicator was all participants get minimum post test score of 80 and at least $80 \%$. The research sample was all participants of Basic Training for Civil Servants Group II 2020 with total number of 16 people. The result shows that the pre-test mean score is 84.5 and the post-test mean score is 97.5, indicating an increase of $15.4 \%$. Based on the questionnaire result, it is found that the online learning method of Public Ethics is effective in achieving learning objective. National insight online learning of Basic Training for Civil Servants Candidates with all its strengths and weaknesses is considered effective in achieving learning objective therefore it can be continued in both new normal and normal condition.
\end{abstract}

Keywords: effectiveness, online learning, national insight, basic training for civil servant candidate 


\section{PENDAHULUAN}

P andemi Covid-19 telah menyerang Indonesia secara masif sejak bulan Maret 2020. Covid-19 merupakan penyakit menular yang disebabkan oleh sindrom pernapasan akut Corona Virus 2. COVID-19 ditetapkan sebagai penyakit yang menimbulkan wabah (Kementerian Kesehatan, 2020). Tidak hanya melumpuhkan sistem sosial dan perekonomian, dampaknya juga terjadi pada hampir seluruh aspek dalam roda kehidupan masyarakat. Mengantisipasi penularan virus tersebut pemerintah telah mengeluarkan berbagai kebijakan, seperti isolasi, social and physical distancing hingga pembatasan sosial berskala besar. Kondisi ini mewajibkan masyarakat untuk tetap tinggal di rumah, bekerja, beribadah dan belajar di rumah. Segala upaya telah dilakukan oleh pemerintah untuk mengurangi kasus penularan Covid-19, termasuk kebijakan dalam pelaksanaan pendidikan dan pelatihan dalam rangka mewujudkan kualitas pejabat publik yang lebih adaptif melalui pemanfaatan teknologi agar dapat menciptakan pelayanan publik yang optimal, efisien, dan efektif. Lembaga Administrasi Negara (LAN) telah mengambil langkah-langkah strategis dalam percepatan pengembangan kompetensi ASN terutama di masa pandemi Covid-19. Kepala LAN dalam Webinar Kemitraan LAN dan Tanoto Foundation Seri I mengatakan bahwa salah satu kebijakan pelaksanaan pengembangan kompetensi yang dikembangkan di LAN adalah melalui pendekatan flexible learning yaitu pembelajaran dilakukan lebih lentur, fleksibel, dapat dilakukan kapan saja dan oleh siapa saja. Pimpinan Lembaga Penyelenggara Pelatihan bertanggung jawab dalam menentukan metode yang tepat berdasarkan perkembangan tingkat bahaya COVID-19 di daerahnya dengan mengutamakan keamananan, keselamatan seluruh peserta pelatihan, tenaga pelatihan dan penyelenggara pelatihan serta tetap dalam rangka pencapaian tujuan pembelajaran.

Seiring dengan kebijakan pelaksanaan pelatihan yang dikeluarkan oleh LAN, penyelenggaraan pelatihan di Balai Diklat Aparatur Kementerian Kelautan dan Perikanan (BDA KKP) mengalami penyesuaian terhadap situasi yang terjadi agar selaras dengan kebijakan yang dikeluarkan oleh pemerintah. Salah satu pelatihan yang terkena dampak tersebut adalah Pelatihan Dasar Calon Pegawai Negeri Sipil (Latsar CPNS). Setelah melalui arahan pimpinan dan berbagai macam pertimbangan, maka Latsar CPNS diputuskan untuk diselenggarakan pada bulan September 2020 dengan penyesuaian metode pelatihan secara daring yang dapat menunjang kesehatan serta keselamatan semua pihak. Dengan memperhatikan berbagai macam aspek, baik dari peserta, pengajar dan penyelenggara sistem pelatihan secara daring masih memungkinkan untuk dilaksanakan di Balai Diklat Aparatur KKP. Putusan ini juga mengacu pada Surat Edaran Kepala LAN Nomor 10 Tahun 2020 tentang Panduan Teknis Penyelenggaraan Pelatihan Dalam Masa Pandemi Covid-19.

Kegiatan Latsar CPNS berjalan melalui platform Learning Management System Balai Diklat Aparatur KKP dan dukungan beberapa aplikasi seperti zoom, telegram dan whatsapp. LMS merupakan perangkat lunak yang bisa mengotomatisasi administrasi dari sebuah training. LMS menggunakan teknologi berbasis web untuk berkomunikasi, berkolaborasi, belajar, transfer ilmu pengetahuan, dan pembelajaran guna menambah nilai kepada peserta didik (Muhammad, 2017). Pembelajaran Latsar CPNS Golongan II Tahun 2020 di Balai Diklat Aparatur KKP, yang sebelum pandemi Covid-19 dilaksanakan secara klasikal berubah menjadi pembelajaran secara daring dari lokasi masing-masing, baik agenda Sikap Perilaku Bela Negara, agenda pembelajaran ANEKA (Akuntabilitas, Nasionalisme, Wawana Kebangsaan, Komitmen Mutu dan Anti Korupsi), Agenda Kedudukan dan Peran PNS dalam NKRI, termasuk saat seminar rancangan aktualisasi, coaching dan mentoring serta seminar laporan aktualisasi.

Perubahan pembelajaran tatap muka menjadi pembelajaran daring secara mendadak berpeluang untuk membuat pembelajaran tidak dapat berjalan dengan maksimal. Banyak kendala dalam pembelajaran online yang sebelumnya tidak pernah dipersiapkan secara matang (Irawati \& Jonatan, 2020). Dengan adanya perubahan metode pembelajaran ini menuntut kesiapan dari semua pihak untuk 
menyesuaikan dengan kondisi ini baik dari penyelenggara, peserta dan tenaga pengajar guna pencapaian tujuan pembelajaran yang optimal bagi peserta (Pratama et al., 2020). Berkaitan dengan adanya penyesuaian metode pembelajaran Latsar CPNS tersebut, penelitian ini bertujuan untuk mengetahui tingkat efektivitas pembelajaran daring materi Wawasan Kebangsaan pada Latsar CPNS Golongan II Tahun 2020 di Balai Diklat Aparatur KKP, apakah penyampaian materi Wawasan Kebangsaan yang dilaksanakan secara daring sudah berjalan dengan efektif yang berarti bahwa tujuan pembelajaran dan kompetensi dasar telah tercapai.

Pembelajaran daring Wawasan Kebangsaan dilaksanakan sebanyak 6 Jam Pelajaran (JP), dengan pembagian untuk sesi tatap muka on line melalui aplikasi zoom selama $3 \mathrm{JP}$, kemudian penugasan mandiri $2 \mathrm{JP}$, dilanjutkan dengan presentasi serta pembahasan penugasan melalui tatap muka on line kembali 1 JP. Bahan ajar berupa modul, video pembelajaran dan bahan tayang sudah diunggah dalam LMS Balai Diklat Aparatur KKP, sehingga diharapkan peserta pelatihan sudah membaca materi sebelum pelaksanaan tatap muka daring dengan pengajar. Sebelum pertemuan tatap muka daring dan pada akhir pertamuan, peserta diminta untuk mengerjakan pre test dan pos test untuk mengetahui tingkat pemahaman sebelum dan sesudah mengikuti pembelajaran.

Kompetensi dasar yang ingin dicapai dalam pembelajaran Wawasan Kebangsaan yakni setelah mengikuti pembelajaran peserta mampu memahami landasan kehidupan berbangsa dan bernegara; nilai-nilai dasar bela negara; penghormatan terhadap lambang-lambang negara dan ketaatan kepada peraturan perundang-undangan; dan pembinaan kerukunan, menjaga persatuan dan kesatuan bangsa.

Sedangkan Indikator Keberhasilan Peserta ditunjukan oleh indikator sebagai berikut: a. Menjelaskan landasan kehidupan berbangsa dan bernegara; $b$. Menjelaskan nilai-nilai dasar bela negara; c. Menjelaskan penghormatan terhadap lambang-lambang negara dan ketaatan kepada peraturan perundang-undangan; $d$. Menjelaskan pembinaan kerukunan, menjaga persatuan dan kesatuan bangsa (Lembaga Administrasi Negara, 2019).

Keberhasilan metode pembelajaran daring dikarenakan adanya interaksi optimal antara peserta pelatihan dan berbagai fasilitas pelatihan, antara peserta pelatihan dan peserta pelatihan lainnya, dan adanya model pembelajaran aktif dalam hubungan tersebut, dan antara peserta pelatihan dan pengajar (Rahman et al., 2020).

Ada beberapa faktor yang menentukan efektivitas pembelajaran secara daring antara lain: (1) Teknologi, secara khusus memastikan peserta memiliki akses yang mudah (misalnya melalui akses jarak jauh); dan jaringan seharusnya membutuhkan waktu minimal untuk pertukaran dokumen. (2) Karakteristik pengajar, pengajar memainkan peran sentral dalam efektivitas pembelajaran secara daring, penerapan instruksional teknologi dari pengajar yang menentukan efek pada pembelajaran, instruktur yang memiliki sifat positif terhadap pendistribusian suatu pembelajaran dan memahami akan sebuah teknologi akan cenderung menghasilkan suatu pembelajaran yang lebih positif. (3) Karakteristik peserta, peserta yang tidak memiliki keterampilan dasar dan disiplin diri yang tinggi dapat melakukan pembelajaran yang lebih baik dengan metode yang disampaikan secara konvensional, sedangkan peserta yang cerdas serta memiliki disiplin serta kepercayaan diri yang tinggi akan mampu untuk melakukan pembelajaran dengan metode daring. Media pembelajaran adalah sarana ataupun instrumen yang mendorong efektifitas dan efisiensi kegiatan pembelajaran, khususnya ketika peserta diharuskan belajar dari rumah selama masa pandemi covid-19 (Batubara \& Batubara, 2020). Berdasarkan pendapat dari beberapa ahli, efektivitas atau keberhasilan metode pembelajaran daring ditentukan oleh teknologi, pengajar dan peserta.

Tulisan ini akan meneliti seberapa efektif metode pembelajaran daring yang diterapkan pada saat pembelajaran Wawasan Kebangsaan. Kemudian mengetahui faktor-faktor apa saja yang mendukung pencapaian efektivitas pembelajaran wawasan kebangsaan.

Penelitian ini dapat bermanfaat dalam beberapa hal yaitu: 
a. Secara teoritis, penelitian ini diharapkan dapat memberikan pengetahuan dan pemahaman khususnya bagi para pengajar materi Wawasan Kebangsaan tentang efektivitas metode pembelajaran daring dalam memberikan pemahaman terhadap nilai nilai Wawasan Kebangsaan kepada peserta Latsar CPNS.

b. Secara praktis, penelitian ini diharapkan dapat memberikan referensi bagi pelaksanaan mata pelatihan Wawasan Kebangsaan Latsar CPNS berikutnya agar dapat berlangsung lebih efektif, khususnya kepada para pengajar.

\section{METODE PENELITIAN}

Penelitian ini mengacu kepada pendekatan kuantitatif. Penelitian kuantitatif didasari pada filsafat positivisme yang menekankan fenomena objektif yang dikaji secara kuantitatif atau dilakukan dengan menggunakan angka, pengolahan statistik, struktur, dan percobaan terkontrol (Sugiyono, 2012). Jenis penelitian ini merupakan penelitian kuasi eksperimen dengan melalui pengumpulan dan analisis terhadap data primer. Penelitian eksperimen merupakan penelitian yang dimaksudkan untuk mengetahui ada tidaknya akibat dari treatment pada subjek yang diselidiki atau penelitian yang digunakan untuk mencari pengaruh perlakuan tertentu terhadap yang lain dalam kondisi yang terkendali (Arikunto, 2010). Penelitian ini akan menyelidiki adakah pengaruh metode pembelajaran daring Wawasan Kebangsaan terhadap efektivitas pencapaian hasil belajar peserta pelatihan. Terdapat beberapa bentuk desain eksperimen yaitu: pre-exsperimental design, true experimental design, factorial design, dan quasi experimental design. Ciri utama dari quasi experimental design adalah pengembangan dari true experimental design, yang mempunyai kelompok kontrol namun tidak dapat berfungsi sepenuhnya untuk mengontrol variabel dari luar yang mempengaruhi pelaksanaan eksperimen (Sugiyono, 2010). Dapat disimpulkan bahwa quasi experimental design adalah jenis desain penelitian yang memiliki kelompok kontrol dan kelompok eksperimen tidak dipilih secara random. Peneliti menggunakan quasi experimental design karena dalam penelitian ini terdapat variabel-varibel dari luar yang tidak dapat dikontrol oleh peneliti. Desain penelitian ini menggunakan model non-equivalent control group. Sebelum diberi treatment, peserta pelatihan diberi test dalam bentuk pre test, dengan maksud untuk mengetahui keadaan subyek sebelum treatment. Kemudian setelah diberikan treatment, subyek diberikan test dalam bentuk post test, untuk mengetahui keadaan subyek setelah treatment.

Penelitian dilaksanakan pada pembelajaran daring materi Wawasan Kebangsaan Latsar CPNS Golongan II Tahun 2020 di Balai Diklat Aparatur KKP yang berlangsung pada hari Selasa 15 September 2020. Subyek Penelitian adalah peserta pelatihan Latsar CPNS Golongan II Angkatan Tahun 2020 yang berjumlah 16 orang. Sedangkan obyek penelitian adalah efektivitas pembelajaran daring materi Wawasan Kebangsaan. Populasi penelitian adalah seluruh peserta Latsar CPNS Golongan II sejumlah 16 orang. Pengumpulan data primer dilaksanakan melalui instrumen penelitian berupa kuisioner, lembar penugasan dan wawancara. Kuesioner yang disusun berisikan pertanyaan tertutup (closed-question) dalam bentuk pilihan jawaban tentang bagaimana pengalaman dan pendapat responden terhadap metode pembelajaran daring Wawasan Kebangsaan yang mereka alami. Pendistribusian kuesioner dilakukan melalui google form di laman http://bit.ly/KuesionerWasBang.

Lembar penugasan diberikan sebanyak dua kali, yang pertama diberikan pada saat peserta belum melaksanakan pembelajaran tatap muka daring (pre test) dan yang kedua diberikan setelah peserta melaksanakan pembelajaran tatap muka daring (post test). Hasil nilai pre test dan post test merupakan salah satu indikator keberhasilan pembelajaran daring Wawana Kebangsaan. Wawancara dilaksanakan dengan peserta dan mentor pendamping agenda habituasi. Instrumen penelitian yang digunakan adalah lembar penugasan, kuesioner online dan pedoman wawancara. indikator efektivitas pembelajaran daring Wawasan Kebangsaan yang digunakan adalah: seluruh peserta mendapatkan nilai post test dengan skor minimal 80 dan minimal $80 \%$ dari jumlah 
peserta pelatihan berpersepsi tinggi atau sangat tinggi terhadap efektivitas pembelajaran. Penetapan indikator efektivitas ini didasarkan pada Peraturan Lembaga Administrasi Negara Nomor 12 Tahun 2018 tentang Pelatihan Dasar CPNS pada pasal 9 disebutkan tentang kualifikasi penilaian evaluasi peserta Latsar CPNS.

Teknik tabulasi sederhana dilakukan untuk menganalisis data yang terkumpul dengan melalui pengelompokan jawaban dari pertanyaan dibuat dalam kuesioner. Penyajian hasil penelitian dideskriptikan sebagai berikut:

a. Analisis data hasil belajar peserta pelatihan

Nilai hasil belajar peserta pelatihan yang diperoleh, kemudian dikelompokkan. Indikator efektivitas pembelajaran adalah seluruh peserta mendapatkan nilai post test dengan skor minimal 80. Hasil belajar dianalisis dengan kriteria sebagai berikut:

Tabel 1. Kriteria Hasil Belajar Skor

Kategori

$\begin{array}{cl}90.01-100 & \text { Sangat Memuaskan } \\ 80.01-90.0 & \text { Memuaskan } \\ 70.01-80.0 & \text { Cukup } \\ 60.1-70.0 & \text { Kurang } \\ \leq 60 & \text { Sangat Kurang }\end{array}$

penghitungan presentase kenaikan hasil belajar peserta pelatihan adalah:

$$
\begin{aligned}
& \text { Presentase } \\
& =\frac{X \text { Post test }-X \text { Pre test }}{X \text { Pre test }} \times 100 \%
\end{aligned}
$$

b. Analisis data hasil kuesioner persepsi efektivitas pembelajaran daring.

Tingkat efektivitas pembelajaran daring Wawasan Kebangsaan diperoleh dengan analisis kuesioner yang disebarkan secara daring kepada peserta pelatihan. Skala likert dapat dipaaki guna mengukur sikap, pendapat dan persepsi seseorang atau kelompok tentang gejala sosial atau fenomena pendidikan (Sugiyono, 2015). Skala likert yang dipakai adalah lima alternatif pilihan jawaban sangat positif sampai sangat negatif. Data hasil kuesioner ini diolah kemudian dianlisis. Indikator efektivitas pembelajaran wawasan kebangsaan tercapai bila minimal $80 \%$ peserta pelatihan menjawab pada kriteria tinggi atau sangat tinggi di setiap item pertanyaan.

\section{TEMUAN DAN PEMBAHASAN}

\section{Temuan}

Peserta Latsar CPNS sebanyak 16 orang. Rentang usia peserta Latsar antara 20 sampai 22 tahun dengan jenis kelamin laki-laki 5 orang dan jenis kelamin perempuan 11 orang.

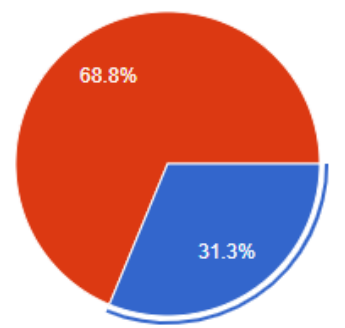

Laki-laki Perempuan

Gambar 1. Diagram Perbandingan Jenis Kelamin Peserta

Koneksi internet buruk menjadi penentu keberhasilan pembelajaran kelas daring. Pelaksanaan pembelajaran materi Wawasan Kebangsaan jaringan internet cukup lancar. Tidak ditemukan kendala pada jaringan internet yang menghambat pembelajaran. mayoritas peserta melaksanakan pembelajaran daring dari tempat tinggal masing-masing. Sedangkan, lokasi pengajar berada di Balai Diklat Aparatur KKP.

Kuesioner disebar melalui google form telah mendapatkan tanggapan dari 16 peserta pelatihan. Hasil kuesioner dan hasil pre testpost test selanjutnya ditabulasi dan diolah menggunakan perhitungan statistik sederhana agar data mudah untuk dibaca dan diinterpretasikan. Hasil olah data kuesioner dan pre-test serta post-test peserta pelatihan adalah sebagai berikut:

Tabel 2. Nilai Pre test

Skor Jml Presentase Kategori

90.01-100 $8 \quad 50 \% \quad$ Sangat

Memuaskan 


$\begin{array}{cccc}\begin{array}{c}80.01- \\ 90.0\end{array} & 2 & 12.5 \% & \text { Memuaska } \\ \begin{array}{c}70.01- \\ 80.0\end{array} & 4 & 25 \% & \text { Cukup } \\ 60.1-70.0 & 2 & 25 \% & \text { Kurang } \\ \leq 60 & - & - & \begin{array}{c}\text { Sangat } \\ \text { Kurang }\end{array}\end{array}$

Nilai pre-test dari 16 peserta menunjukan bahwa 8 peserta (50\%) mendapat nilai sangat memuaskan, 2 peserta $(12.5 \%)$ mendapatkan nilai memuaskan, 4 peserta (25\%) mendapatkan nilai cukup, 2 peserta $(12.5 \%)$ mendapatkan nilai kurang. Tidak ada peserta yang mendapatkan nilai sangat kurang. Nilai rata-rata hasil pre test adalah 84.5 (memuaskan).

\begin{tabular}{|c|c|c|c|}
\hline \multicolumn{4}{|c|}{ Tabel 3. Nilai Post test } \\
\hline Skor & Jml & $\begin{array}{c}\text { Presentas } \\
\mathrm{e}\end{array}$ & Kategori \\
\hline $90.01-100$ & 15 & $97 \%$ & $\begin{array}{c}\text { Sangat } \\
\text { Memuaskan }\end{array}$ \\
\hline $\begin{array}{l}80.01- \\
90.0\end{array}$ & 1 & $3 \%$ & Memuaskan \\
\hline $\begin{array}{l}70.01- \\
80.0\end{array}$ & - & - & Cukup \\
\hline $60.1-70.0$ & - & - & Kurang \\
\hline$\leq 60$ & - & - & $\begin{array}{l}\text { Sangat } \\
\text { Kurang }\end{array}$ \\
\hline
\end{tabular}

Berdasarkan tabel nilai post test di atas, dari 16 peserta $(100 \%)$ mendapatkan nilai dengan skor memuaskan. Nilai rata-rata post test adalah 97.50 (sangat memuaskan).

Berikut disajikan grafik peningkatan hasil belajar berdasarkan nilai pre test dan post test.

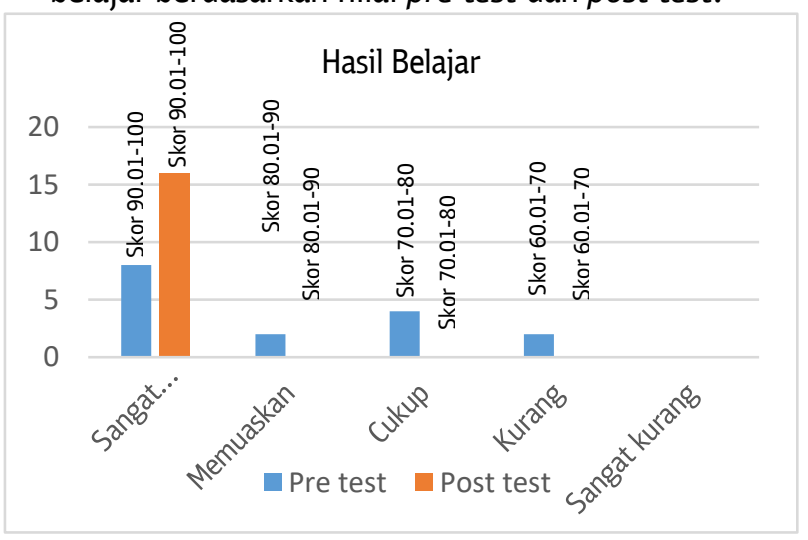

Gambar 2. Peningkatan Hasil Belajar

Grafik menunjukan peningkatan hasil belajar peserta dari pre test dan post test. Pada saat pre test masih ada peserta yang mendapatkan nilai cukup, sedangkan saat post test semua peserta mendapatkan nilai memuaskan dan sangat memuaskan. Berdasarkan rumus perhitungan peningkatan hasil belajar peserta, peningkatan hasil belajar pada saat pre test dan post test adalah sebesar $15.4 \%$.

Gambar 3. Skor Tertinggi dan Terendah

Grafik menunjukan bahwa nilai pre test terendah adalah 607 dan tertinggl adalah 100. Pada post test, nilai terendah adalah 92 dan nilai tertinggi adalah 100 .

Tabel 4. Persepsi Materi Disampaikan dengan Menarik

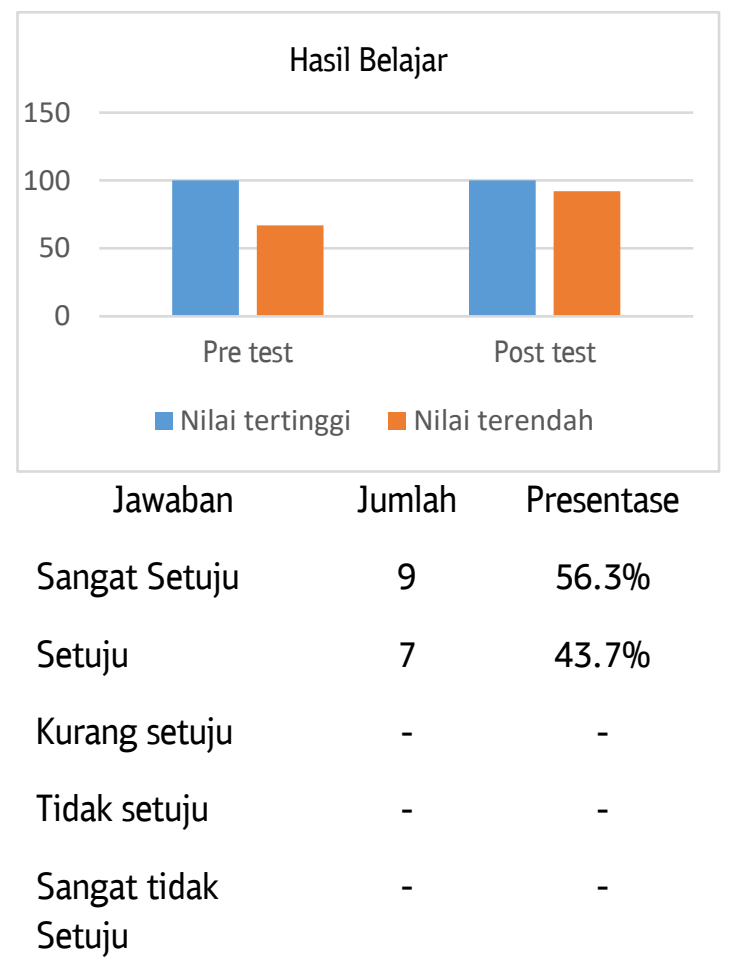

Persepsi peserta pelatihan tentang seberapa besar materi wawasan kebangsaan disampaikan dengan menarik adalah sebagai berikut: 9 peserta atau $56.3 \%$ berpendapat sangat sesuai, 7 peserta atau $43.8 \%$ berpendapat sesuai. Data ini menunjukkan bahwa sebagian besar peserta sudah menganggap bahwa materi yang disampaikan secara menarik. Secara 
keseluruhan sebanyak $100 \%$ peserta pelatihan menjawab dengan kriteria sesuai atau sangat sesuai.

Tabel 5. Pemahaman Materi Jawaban Jumlah Presentase

Sangat paham
Paham
Kurang paham
Tidak paham
Sangat tidak
paham

Dari persepsi pemahaman materi, sebanyak 12 peserta $(75 \%)$ berpendapat sudah sangat paham dengan materi yang disampaikan, 4 peserta $(25 \%)$ berpendapat sudah paham. Tidak ada peserta yang menjawab dengan jawaban kuarng paham, tidak paham dan sangat tidak paham. Dari data yang diperoleh menunjukkan bahwa 100\% dari peserta dapat memahami materi yang disampaikan melalui pembelajaran daring dengan kriteria paham dan sangat paham.

Tabel 6. Persepsi Kelebihan Pembelajaran Daring Jawaban Jumlah Presentase

$\begin{array}{lcc}\text { Sangat menarik } & 8 & 50 \% \\ \text { Menarik } & 8 & 50 \% \\ \text { Kurang menarik } & - & - \\ \text { Tidak menarik } & - & - \\ \begin{array}{l}\text { Sangat tidak } \\ \text { menarik }\end{array} & - & -\end{array}$

Persepsi peserta Latsar tentang kelebihan pembelajaran daring dalam pembelajaran wawana kebangsaan adalah sebagai berikut: 8 peserta $(50 \%)$ berpendapat metode pembelajaran daring tersebut sangat menarik, 8 peserta $(50 \%)$ berpendapat bahwa materi pelatihan menarik. Tidak ada peserta yang berpersepsi kurangmenaik, tidak menari dan tidak menarik sama sekali. Secara keseluruhan
$100 \%$ peserta sudah berpendapat bahwa materi yang disampaikan menarik. Berdasarkan hasil wawancara, diperoleh informasi bahwa pembelajaran daring menyenangkan, tidak membosankan, lebih mudah, dan fleksibel, lebih menuntut kedewasaan sikap dan tanggung jawab. Untuk menguasai materi, peserta tidak mengandalkan pengajar, namun peserta aktif berusaha secara mandiri untuk memahami materi dan mencari berbagai referensi terkait.

Tabel 7. Persepsi Efektivitas Pembelajaran Jawaban Jumlah Presentase

$\begin{array}{lcc}\text { Sangat efektif } & 9 & 56.3 \% \\ \text { Efektif } & 6 & 37.5 \% \\ \text { Kurang efektif } & 1 & 6.2 \% \\ \text { Tidak efektif } & - & - \\ \text { Sangat tidak efektif } & - & -\end{array}$

Pada pertanyaan, apakah pembelajaran daring efektif untuk mencapai tujuan pembelajaran, 9 orang peserta $(56.5 \%)$ berpendapat bahwa pembelajaran daring sangat efektif dalam capaian tujuan pembelajaran, 6 peserta $(37.5 \%)$ menjawab efektif, 1 peserta (6.2\%) menjawab kurang efektif. Sebanyak $93.8 \%$ peserta sudah menganggap bahwa pembelajaran daring ini sudah efektif. Pada proses wawancara, didapat hasil informasi yang menyatakan bahwa mereka tidak mempermasalahkan pembelajaran daring maupun luring.

\section{Tabel 8. Keaktifan Peserta}

Jawaban Jumlah Presentase

$\begin{array}{lcc}\text { Sangat aktif } & 10 & 62.5 \% \\ \text { Aktif } & 5 & 31.3 \% \\ \text { Kurang aktif } & - & - \\ \text { Tidak aktif } & - & - \\ \text { Sangat tidak aktif } & 1 & 6.2 \%\end{array}$

Keaktifan peserta dalam kegiatan pembelajaran dapat dideskripsikan bahwa 10 orang peserta $(62.5 \%)$ sangat aktif terlibat 
dalam pembelajaran, 5 peserta (31.3\%) aktif terlibat, 1 peserta (6.2\%) sangat tidak aktif. Hasil wawancara menunjukan bahwa peserta telah diberikan secara luas dalam berpendapat atau bertanya. Ada kecenderungan keaktifan peserta tertentu saja. Ada peserta yang merasa kurang mendapatkan perhatian dari pengajar. Pengajar, pada kelas tatap muka lebih mudah mengawasi peserta yang terlihat belum aktif.

Tabel 9. Penerapan Nilai-nilai Wawasan Kebangsaan Jawaban Jumlah Presentase

$\begin{array}{lll}\text { Sangat mampu } & 9 & 56.3 \% \\ \text { Mampu } & 7 & 43.7 \%\end{array}$

Kurang mampu

Tidak mampu

Sangat tidak mampu

Pada pertanyaan mengenai penerapan nilai-nilai Wawasan Kebangsaan, 9 orang peserta $(56.3 \%)$ menyatakan sangat mampu menerapkan nilai-nilai, 7 peserta $(43.7 \%)$ menyatakan mampu. Tidak dtemukan data peserta yang menyatakan kurang mampu. Berdasarkan wawancara dengan peserta dan beberapa mentor pembimbing habituasi, peserta pelatihan menerapkan nilai-nilai Wawana Kebangsaan dengan baik.

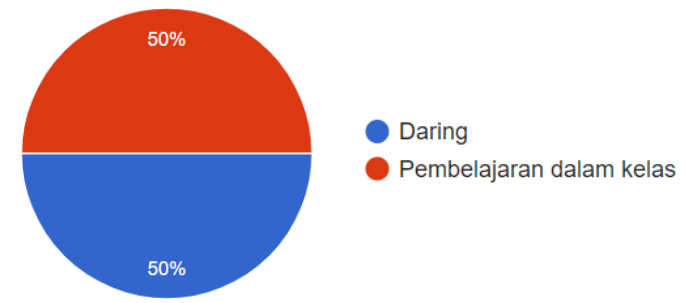

Gambar 4. Metode Pembelajaran yang Disenangi

Pada pertanyaan tentang metode belajar yang lebih disenangi, 8 orang peserta $(50 \%)$ diperoleh hasil bahwa bahwa peserta lebih senang mengikuti pembelajaran secara daring, sedangkan 8 peserta lainnya (50\%) lebih senang dengan pembelajaran dalam kelas. Hasil wawancara menunjukan bahwa peserta yang memilih pembelajaran daring lebih karena untuk menjaga jarak untuk megurangi penyebaran virus, lebih fleksibel karena mereka bisa belajar dimana saja serta tidak diinapkan. Pada pertanyaan selanjutnya bila kondisi sudah normal kembali, sebagian besar dari menginginkan untuk belajar di dalam kelas. Peserta yang menghendaki pembelajaran dalam kelas, menganggap mudah memahami nilai-nilai yang disampaikan secara langsung oleh pengajar.

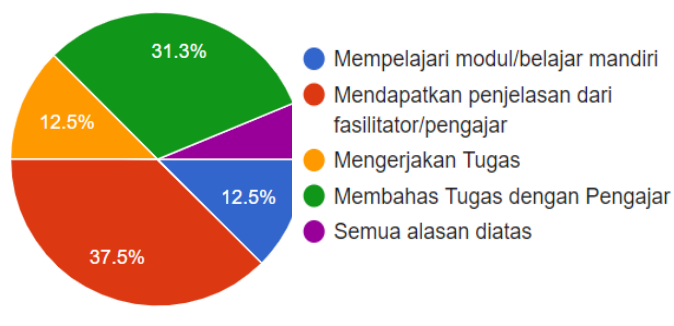

Gambar 5. Sumber Pemahaman Materi

Pada pertanyaan bahan ajar dalam memahami nilai-nilai Wawasan Kebangsaan, sebanyak 2 peserta $(12.5 \%)$ menjawab saat membaca modul, 16 peserta (37.5\%) menjawab saat mendapatkan penjelasan oleh pengajar, 2 peserta $(12.5 \%)$ menjawab saat mengerjakan tugas dan 3 peserta $(31.3 \%)$ menjawab saat melakukan pembahasan tugas dengan pengajar dan 1 peserta (6.2\%) menjawab gabungan dari berbagai macam sumber. Chart menujukan sebagian besar peserta memberikan jawaban mereka dapat memahami materi saat dijelaskan oleh pengajar, ini mengindikasikan bahwa kehadiran pengajar dalam pembelajaran daring sangat penting. Peran teknologi tidak dapat menjawab kebutuhan dalam pelatihan.

Berdasarkan hasil wawancara dengan Mentor pendamping habituasi yang rata-rata adalah atasan dari peserta, diperoleh informasi bahwa selama pelaksanaan habituasi maupun pada saat bekerja, peserta menunjukkan sikap dan perilaku yang sesuai dengan nilai-nilai dasar wawasan kebangsaan. Hasil pengamatan mentor menunjukan bahwa para peserta bersikap dan perilaku sesuai dengan nilai-nilai wawasan kebangsaan. Tidak ditemukan adanya pelanggaran selama proses mentoring.

\section{Pembahasan}

Rata-rata nilai pre test 84.5 dan nilai post test 97.5 setelah peserta melakukan proses belajar. Hal ini menunjukkan adanya peningkatan hasil belajar sebesar $15.4 \%$ setelah mengikuti pembelajaran online. Hasil 
wawancara terhadap beberapa peserta menunjukan sebagian besar peserta sudah membaca modul, diterapkan dengan baik saat mengerjakan soal pre test. Setelah dilaksanakan pembelajaran daring, peserta semakin memahami materi. Pembahasan Pembelajaran dilakukan pada materi yang belum dipahami oleh peserta, berdasarkan tanggapan peserta dan hasil pre test. Semua peserta memperoleh nilai di atas 80 saat post test. Indikator efektivitas pelatihan telah tercapai berdasarkan nilai post test menunjukkan bahwa.

Tidak ada kendala dalam pencapaian tujuan pembelajaran. Artinya, Seluruh peserta (100\%) dapat memahami materi yang disampaikan secara daring. Dari sisi persepsi materi disampaikan dengan menarik, seluruh peserta (100\%) menganggap bahwa materi telah disampaikan secara menarik dan tidak monoton, meskipun pembelajaran dilakukan melalui aplikasi zoom. Peserta menilai bahwa materi yang disampaikan sudah sesuai dengan modul pelatihan. Setelah mengerjakan tugas dan melakukan pembahasan, beberapa peserta merasa lebih paham. Setiap pernyataan maupun pertanyaan dari pengajar, peserta aktif menaggapi.

Penyampaian materi dengan menarik dan interaktif dilakukan pengajar supaya peserta dapat terlibat secara aktif. Keterbatasan layar komputer menjadi kendala karena tidak bisa menjangkau dan melihat peserta secara keseluruhan. Beberapa peserta merasa kurang mendapatkan perhatian saat pembelajaran berlangsung. Perlu ditingkatan fasilitas perangkat supaya para pengajar dapat menyampaikan materi serta dapat berinteraksi dengan seluruh peserta.

Sebanyak $93.8 \%$ peserta menyataan bahwa mereka aktif dalam proses pembelajaran melalui fitur chat maupun diskusi langsung. Untuk mendapatkan kesempatan bicara, peserta tunjuk tangan. keterbatasan waktu menjadi kendala peserta dalam menyampaikan pendapat. Bagi pengajar perlu mengelola waktu dengan baik agar proses diskusi dapat berlangsung lebih efektif. Pada segi kemampuan dalam penerapan nilai-nilai Wawasan Kebangsaan, Sebesar 100\% peserta menyatakan bahwa mereka sangat mampu dan mampu untuk menerapkan nilai-nilai wawasan kebangsaan. Hal ini menunjukkan bahwa peserta dapat menerima dan memahami materi dengan baik.

Pada sisi sumber pemahaman materi, $37.5 \%$ peserta menyatakan paham setelah mendapatkan penjelasan dari pengajar. penjelasan pengajar sangat penting untuk pencapaian tujuan pembelajaran yakni pemahaman peserta tentang nilai-nilai wawasan kebangsaan.

Kehadiran pengajar sangat berarti pembelajaran yang dilaksanakan secara daring. Pengajar, dalam menyampaikan materi harus dapat menyesuaikan dengan dengan peserta yang dihadapi. Peserta pelatihan cenderung lebih suka untuk diajak berdiskusi membahas isu-isu terkini yang berkaitan dengan penerapan nilai-nilai wawasan kebangsaan. Bahan tayang yang menarik dan bervariasi, gaya bicara dan intonasi yang tidak terkesan menggurui serta penugasan yang menantang akan sangat membantu penyampaian materi dapat diterima oleh peserta.

Pembelajaran daring ini dikatakan efektif, namun ternyata sebagian dari peserta menginginkan pelaksanaan pembelajaran langsung dalam kelas, karena melalui pembelajaran dalam kelas mereka mendapatkan pengalaman langsung, bertemu dengan pengajar dan rekan-rekan secara langsung sehingga nila-nilai yang ditanamkan akan lebih mudah diterapkan. Minimnya sentuhan emosional antara pengajar dengan peserta merupakan kekurangan dari pelaksanaan pembelajaran daring wawasan kebangsaan. Berbeda dengan pembelajaran daring, pengajar pada pembelajaran dalam kelas dapat berinteraksi langsung dengan peserta.

Peserta tidak mengalami kendala pada penguasaan materi dan teknis. Jaringan internet yang digunakan relatif stabil, dukungan perangkat yang memadai. Peserta dapat dengan mudah untuk mengoperasionalkan LMS BDA KKP dan tidak mengalami kesulitan. Peserta merasa lebih bertanggung jawab dalam penguasaan materi, mereka lebih aktif dalam mempelajari setiap materi, aktif mencari sumber bacaan lain yang terkait, dan mereka tidak mengandalkan fasilitator. 
Peserta yang memberikan masukan supaya pengajar dalam menyampaikan materi tidak terlalu cepat. Sebagai solusi adalah peserta dapat memaksimalkan JP yang ada, JP yang dialokasikan dapat digunakan untuk membahas materi dan berdiskusi langsung dengan pengajar, dan penugasan dilakukan di luar JP. Saran peserta agar pengajar menggunakan dua layar dalam kegiatan pembelajaran, satu layar untuk penyempaian materi dan layar lagi untuk berinteraksi dengan peserta, sehingga kelas lebih hidup dan komunikatif.

\section{PENUTUP}

\section{Simpulan}

Berdasar pembahasan yang telah disamapaikn, kesimpulan penelitian adalah sebagai berikut:

a. Rata-rata nilai pre test adalah 84.5 (memusakan) dan rata-rata nilai post test adalah 97.5 dengan (sangat memuaskan) pada hasil belajar. Adanya peningkatan sebesar $15.4 \%$ dari rata-rata nilai pre test ke nilai post test. Hasil analisis data mengenai persepsi dari peserta pelatihan, pada setiap pertanyaaan, lebih dari $80 \%$ peserta sudah memberikan jawaban yang masuk dalam kategori tinggi dan sangat tinggi. Hasil belajar dan persepsi peserta mengenai pembelajaran dari telah memenuhi kriteria yang ditetapkan dalam indikator keberhasilan.

b. Pada Latsar CPNS Golongan II Tahun 2020 ini, metode pembelajaran daring Wawasan Kebangsaan dinilai efektif dalam mencapai tujuan pembelajaran hal ini terlihat dari keberhasilan dalam mencapai indikator pembelajaran yang ditetapkan.

c. Faktor yang mendukung pencapaian efektivitas pembelajaran wawasan kebangsaan secara daring adalah: pemilihan pengajar dalam pada metode dan media pembelajaran, keterampilan penyampaian materi dan keterampilan dalam menghadapi peserta, serta dukungan sarana dan prasarana yang memadai. d. Tujuan pembelajaran dapat tercapai dengan baik, namun terdapat peserta yang menginginkan pembelajaran langsung dalam kelas untuk dapat merasakan pengalaman pembelajaran yang langsung disampaikan oleh pengajar.

\section{Rekomendasi}

a. Bagi Penyelenggara Pelatihan

Pembelajaran daring Wawasan Kebangsaan pada Latsar CPNS Golongan II Tahun 2020 dinilai efektif. Metode pembelajaran Latsar CPNS daring patut untuk dipertimbangkan dilanjutkan.

b. Bagi Pengajar

Penelitian ini dapat dijadikan referensi bagi para pengajar materi wawasan kebangsaan pada Pelatihan Latsar CPNS. Metode pembelajaran daring yang interaktif dan efektif dalam mencapai tujuan pembelajaran perlu disesuaikan dengan kondisi dan kemampuan peserta. 


\section{DAFTAR PUSTAKA}

Arikunto. (2006). Metode Penelitian. Metode Penelitian.https://doi.org/10.1017/CB09781107415324.004

Batubara, H. H., \& Batubara, D. S. (2020). Penggunaan Video Tutorial Untuk Mendukung Pembelajaran Daring Di Masa Pandemi Virus Corona. Muallimuna: Jurnal Madrasah Ibtidaiyah, 5(2), 21. https://doi.org/10.31602/muallimuna.v5i2.2950

Irawati, D. Y., \& Jonatan, J. (2020). Evaluasi Kualitas Pembelajaran Online Selama Pandemi Covid-19: Studi Kasus di Fakultas Teknik, Universitas Katolik Darma Cendika. Jurnal Rekayasa Sistem Industri, 9(2),135-144. https://doi.org/10.26593/jrsi.v9i2.4014.135-144

Kementerian Kesehatan. (2020). Keputusan Menteri Kesehatan Nomor HK.01.07/MENKES/104/2020 tentang Penetapan Infeksi Novel Coronavirus (Infeksi 2019-ncov) Sebagai Penyakit yang Dapat Menimbulkan Wabah dan Upaya Penanggulangannya.

Lembaga Administrasi Negara. (2015). Modul Wawasan Kebangsaan Latsar CPNS Golongan III.

Lembaga Administrasi Negara. (2018). Peraturan Lembaga Administrasi Negara Republik Indonesia Nomor 12 Tahun 2018 Tentang Pelatihan Dasar Calon Pegawai Negeri Sipil. Lembaga Administrasi Negara Republik Indonesia.

Muhammad, T. (2017). Perancangan Learning Management System Menggunakan Konsep Computer Supported Collaborative Learning. Jurnal Produktif. https://doi.org/ISSN: 2548-8082

Pratama, L. D., Lestari, W., \& Astutik, I. (2020). Efektifitas Penggunaan Media Edutainment Di Tengah Pandemi Covid-19. AKSIOMA: Jurnal Program Studi Pendidikan Matematika, 9(2), 413-423. https://doi.org/10.24127/ajpm.v9i2.2783

Prihantony, D. I. (2020). Efektivitas Metode Pembelajaran Permainan Pada Mata Pelatihan Kesiapsiagaan Bela Negara Dalam Latihan Dasar Calon Pegawai Negeri Sipil. Jurnal Monas Vol 2 No 1 (2020) : 124-134 Juni 2020, 2(1), 124-134.

Rahman, M. A., Amarullah, R., \& Hidayah, K. (2020). Evaluasi Penerapan Model Pembelajaran E-Learning pada Pelatihan Dasar Calon Pegawai Negeri Sipil. Jurnal Borneo Administrator, 16(1), 101-116. https://doi.org/10.24258/jba.v16i1.656

Sugiyono. (2015). Metode Penelitian. In Metode Penelitian. Alfabeta.

Suharsono, A. (2020). Pembelajaran Daring Latsar CPNS From Home Dalam Masa Pandemi Covid-19. Jurnal Susunan Artikel Pendidikan) Vol. 5 No. 1 Agustus 2020, 5(1). 